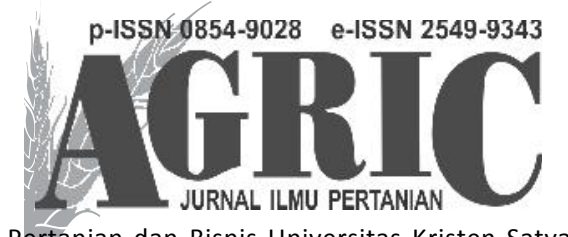

Fakultas Pertanian dan Bisnis Universitas Kristen Satya Wacana Jl. Diponegoro 52-60 SALATIGA 50711 - Telp. 0298-321212 ext 354 email: agric_fpb@yahoo.co.id, website: ejournal.uksw.edu/agric

\title{
MODEL PARTISIPASI MASYARAKAT PINGGIR SUNGAI \\ DALAM PROGRAM PENGELOLAAN LINGKUNGAN PERMUKIMAN BERBASIS KOMUNITAS DI KELURAHAN PAHANDUT SEBERANG KOTA PALANGKA RAYA KALIMANTAN TENGAH
}

\section{PARTICIPATION MODEL OF COMMUNITY-WATERSHED IN COMMUNITY- BASED SETTLEMENT MANAGEMENT PROGRAM IN PAHANDUT SEBERANG URBAN VILLAGE, PALANGKA RAYA CITY CENTRAL KALIMANTAN PROVINCE}

\author{
Eti Dewi Nopembereni \\ Fakultas Pertanian Universitas Palangka Raya, Kalimantan Tengah \\ etidewin@yahoo.co.id \\ Sugiyanto \\ Fakultas Pertanian Universitas Brawijaya
}

Diterima 27 April 2017, disetujui 30 Juni 2017

\begin{abstract}
Community-based Settlement Management Program (PLPBK) is a Central GovernmentProgram through the Ministry of Public Works, which aims to create a harmonious community life order with a safe, comfortable and healthy living environment, self-sustaining and sustainable, and has high economic value for its citizens. This study aims to 1). Identify programs related to the level of community participation, 2) Analyze community-owned social capital, 3) Analyze community behavior on program activities. Determining the location is "purposively" as the site is a top priority on Community-Based Settlement Environmental Management Program (PLPBK). Random sampling was 30 people. Primary data sources are households and secondary data obtained from BPS and related agencies. The results showed that the level of community participation in PLPBK activities was high (46.41\%), the absorption of funds reached $98 \%$ and there has been a significant change in community behavior under the PLPBK Program.
\end{abstract}

Keywords: Settlement Environment, Participation, Social Capital, Behavior 


\begin{abstract}
ABSTRAK
Program Pengembangan Lingkungan Permukiman Berbasis Komunitas(PLPBK) adalah Program Pemerintah Pusat melalui Kementerian Pekerjaan Umum, yang bertujuan untuk mewujudkan tatanan kehidupan masyarakat yang lebih harmonis dengan lingkungan hunian yang aman, nyaman dan sehat, berjati diri dan lestari, serta memiliki nilai ekonomi tinggi bagi warganya.Kajian ini bertujuan; 1)Mengidentifikasi program terkaittingkat partisipasi masyarakat, 2) Menganalisis modal sosial yang dimiliki masyarkat, 3) Menganalisis perilaku masyarakat terhadap program kegiatan. Penentuan lokasi secara"purposive"dengan alasan lokasi tersebut merupakan prioritas utama dari kegiatan Pengelolaan Lingkungan Permukiman Berbasis Komunitas (PLPBK). Penentuan sampel secara randomsebanyak 30 orang. Sumber data primer adalahrumah tangga dan data sekunder yang diperoleh dari BPS dan instansi terkait. Hasil penelitian menunjukkan tingkat partisipasi masyarakat dalam kegiatan PLPBK tergolong tinggi $(46,41 \%)$,serapan dana mencapai 98\% dantelah terjadi perubahan perilaku masyarakat yang signifikan dengan adanya PLPBK tersebut.
\end{abstract}

Kata Kunci: Lingkungan Pemukiman, Partisipasi, Modal Sosial, Perilaku

\section{PENDAHULUAN}

\section{Latar Belakang}

Program Pengembangan Lingkungan Permukiman Berbasis Komunitas (PLPBK) merupakan Program Pemerintah Pusat melalui Kementerian Pekerjaan Umum dengan melibatkan PNPM-Mandiri Perkotaan yang bertujuan mewujudkan tatanan kehidupan masyarakat yang lebih baik dan harmonis dengan lingkungan hunian yang aman, nyaman dan sehat, tertib, selaras,berjati diri dan lestari, sertakawasan yang memiliki nilai ekonomi yang tinggi bagi setiap warga masyarakat. Untuk mencapai tujuan program tersebut diperlukan keterlibatan (partisipasi) aktif masyarakat yangdidukung olehinstansi pemerintah serta pihak lain yang terkait di sekitar lingkungan pengembangan pemukiman tersebut.

Implementasi program dalam kegiatan PLPBK tersebut ternyata ada permasalahan yang terkait dengan rendahnya partisipasi masyarakat dalampenyusunan rencana penataan perumahan dan kawasan permukiman serta lingkungan pada kawasan prioritas dan belum optimalnya hasil pembangunan di kawasan tersebut sesuai dengan aturan tata ruang dan bangunan serta lingkungan yangdisepakati bersama dalam meningkatkan kualitas lingkungan berbasis pada partisipasi masyarakat.

Kelurahan Pahandut Seberang secara geografis terletak di wilayah kecamatan Pahandut kota Palangka Raya dengan jarak tempuh menuju kelurahan tersebut sekitar 15 menit dari pusat kota Palangka Raya. Secara demografis kelurahan Pahandut Seberang merupakan salah satu dari enam kelurahan yang berada di kota Palangka Raya, meliputi: Kelurahan Pahandut, Kelurahan Tumbang Rungan, Kelurahan Langkai, Kelurahan Panarung, Kelurahan Tanjung Pinang serta Kelurahan Bukit Batu.

Kelurahan Pahandut Seberang memiliki Luas areal kuranglebih 725 Ha yang dilintasi oleh Sungai Kahayan, merupakan salah satu sungai terpanjang di Kalimantan Tengah, masyarakatnya hampir $90 \%$ menggantungkan usahanya di bidang perikanan untuk menopang ekonomi rumah tangga. Keunikan dari kawasan ini adalah bangunan yang ditempati masih mempertahankan bangunan lokal berkonstruksi kayu dengan arsitektur tradisional. Kawasan ini merupakan awal mula terbentuknya pemukiman di kota Palangka Raya, diawali dari pinggiran 
sungai, lebih banyak berupa rumah panggung dan terapung sehingga bisamenyesuaikan dengan kondisi alam pinggiran sungai yang sering mengalami pasang surut. Permasalahannya adalah dengan adanya PLPBK masyarakat belum merasakan keterlibatan langsung, selain dampaknya terhadap perubahan perilaku dan pertumbuhan ekonomi serta modal sosial dengan adanya Program Pengelolaan Lingkungan Permukiman Berbasis Komunitas tersebut.

Beragam definisi yang dikemukakan tentang partisipasi, namun secara harfiah, partisipasi berarti "turut berperan serta dalam kegiatan". Secara luas partisipasi dimaknai sebagai' bentuk keterlibatan dan keikutsertaan masyarakat secara aktif dan sukarela, baik karena alasanalasan dari dalam dirinya intrinsik) maupun dari luar dirinya (ekstrinsik) dalam keseluruhan proses kegiatan yang bersangkutan. Partisipasi masyarakat merupakan keikutsertaan masyarakat dalam proses pengidentifikasian masalah dan potensi yang ada di masyarakat, pemilihan dan pengambilan keputusan tentang alternatif solusi untuk menangani masalah, pelaksanaan upaya mengatasi masalah, dan keterlibatan masyarakat dalam proses mengevaluasi perubahan yang terjadi. Oleh karena itu, konsep pembangunan partisipatif mengandung tiga unsur penting, yaitu: (1) Peningkatan peran masyarakat dalam perencanaan, implementasi, pemanfaatan hasil, dan evaluasi proses pembangunan, (2) Orientasi pemahaman masyarakat akan peran tersebut, dan (3) Peran pemerintah sebagai fasilitator, (Hikmat, 2014; Yuliati, 2012).

Lebih lanjut pendekatan partisipatif yaitu dengan melibatkan kerjasama sama antar masyarakat dan pemerintah dengan cara perluasan kesempatan kerja dalam bentuk pengelolaan secara bersama, dimana masyarakat berpatisipasi aktif baik dalam perencanaan sampai pada pelaksanaan kegiatan, ini dilakukan dengan tujuan untuk meningkatkan kesejahteraan masyarakat dengan cara perluasan kesempatan kerja. Sehingga partisipasi sebagai suatu program dalam pengembangan masyarakat dapat digunakan secara luas. Sebagai sebuah konsep sentral, prinsip partisipasi adalah pengembangan masyarakat melalui pembangunan yang efektif sehingga membutuhkan keterlibatan yang nyata dari semua pihak pemangku kepentingan dalam penyusunan program kegiatan, (Mardjoeki, $\mathrm{H}$. 2012; Purwatiningsih, A Ismani, 2014).

Kajian terdahulu oleh Parma (2011), yang memotivasi masyarakat dalam keterlibatannya pada suatu kegiatan adalah; 1). Bahwa faktor ekonomi merupakan motivasi utama, 2). Faktor pelestarian budaya terkait dengan cara hidup suatu kelompok masyarakat, 3). Faktor Lingkungan, kesadaran masyarakat bahwa lingkungan sebagai sumber kehidupan juga mendorong mereka untuk berusaha menjaga dan melestarikan lingkungannya. Tanpa peran serta masyarakat lokal secara terpadu dan berkelanjutan maka akan sulit untuk mewujudkan pelestarian lingkungan yang berkesinambungan.

Sedangkan Genius (2013), menyatakan bahwa partisipasi masyarakat dalam bentuk pemikiran, dalam memberikan tanggapan terhadap informasi belum maksimal hal ini ditunjukkan dengan kehadiran msyarakat saat diadakannya rapat dan adanya motivasi untuk mencari tahu tentang informasi masih rendah. Bentuk partisipasi dalam pemikiran yang lainnya adalah masyarakat dalam perencanaan pembangunan ditemukan sudah sesuai dengan harapan Pemerintah yaitu masyarakat ikut aktif merencanakan pembangunan serta ikut menentukan prioritas usulan program yang ingin dibuat. Selanjutnya pada bentuk partisipasi dalam pelaksanaan operasional pembangunan ditemukan bahwa partisipasi masyarakat sudah menyentuh semua 
lapisan masyarakat khususnya dalam bekerja, sebagian besar masyarakat berperan aktif, namun kegiatan masih di dominasi oleh pihak laki-laki, termasuk partisipasi masyarakat dalam memberikan swadaya berupa tenaga, pikiran dan materi. Sedangkan pada bentuk partisipasi dalam memelihara hasil pembangunan ditemukan bahwa masyarakat belum semuanya berperan aktif memanfaatkan dan merawat pembangunan hanya sebatas pada kelompok pemanfaat langsung pembangunan saja.

Kajian lain menyatakan bahwa tingkat partisipasi masyarakat dalam pembangunan dibeberapa wilayah di Indonesia cukup beragam terkait faktor-faktor yang mempengaruhi tingkat partisipasinya, antara lain; Fadil (2013), bahwa partisipasi masyarakat dalam pelaksanaan musrenbangkel telah sesuai dengan pedoman dan sasaran yang ditetapkan dimana dalam pelaksanaanya terbuka ruang partisipasi masyarakat dalam memberikan usulan perencanaan pembangunan di kelurahan melalui aktor-aktor masyarakat, termasuk partisipasi masyarakat dalam segi kehadiran peserta sudah representatif. Dari sisi komunikasi dalam masyarakat sudah berjalan dengan baik dan sudah bersifat dua arah. Namun dalam pengambilan keputusan realisasi kegiatan tetap di tangan pemerintah, akan tetapi masih minimnya kontrol dan pengawasan dari masyarakat dan pemerintah. Sementara itu peran pemerintah kecamatan berfungsi sebagai motivator, fasilitator, monitoring dan evaluasi. Olfie L. S, (2015), bahwa tingkat partisipasi masyarakat berada pada kategori sedang, karena pada tahap perencanaan sebagian besar responden kurang aktif dalam berpartisipasi dengan alasan sibuk bekerja dan pada tahap pelaksanaan responden terbanyak berada pada tidak aktif berpartisipasi dengan alasan panitia program pembangunan infrastruktur perdesaan tidak konsisten dengan hasil rapat atau keputusan yang diambil dalam tahap perencanaan berbeda dengan pelaksanaannya. Sedangkan partisipasi terbesar ada pada tahap pemeliharaan hal ini dikarenakan responden sudah merasakan hasil dari pembangunan tersebut.

Sedangkan hasil kajian Kogoya (2015), bahwa partisipasi masyarakat dapat diukur dalam tiga kategori, yaitu: partisipasi masyarakat tingkat tinggi, partisipasi masyarakat tingkat sedang dan partisipasi masyarakat tingkat rendah, dimulai dari perencanaan, pelaksanaan, dan pemeliharaan dilihat dari keaktifan sampai dengan tidak aktif. Bahwa Karakteristik desa yang ditinjau dari aspek ekonomi, sosial budaya, dan geografi serta tingkat pendidikan masyarakat memiliki korelasi terhadap tinggi rendahnya tingkat partisipasi masyarakat. Partisipasi masyarakat di seluruh desa memiliki bentuk yang seragam yaitu partisipasi dalam bentuk sumbangan tenaga, material, dan dana. Asnar (2016), menyatakan hasil penelitian menunjukkan bahwa dalam pemanfaatan hasil pembangunan, partisipasi masyarakat masih rendah karena hasil pembangunan yang disediakan tidak digunakan sebagaimana mestinya, serta tidak dijaga dan dirawat dengan baik. Hambatan partisipasi masyarakat adalah rendahnya pemahaman masyarakat akan pentingnya partisipasi mereka dalam mensukseskan pembangunan dan minimnya sosialisasi oleh pihak pemerintah kepada masyarakat terkait informasi pembangunan.

Berdasarkan permasalahan dan konsep partisipasi tersebut maka kajian ini melihat seberapa besar tingkat partisipasi masyarakat pinggir sungai dalam pengelolaan lingkungan permukiman, serta faktor-faktor yang berdampak langsung terhadap perubahan perilaku dan peningkatan aktivitas usaha apabila masyarakat dilibatkan oleh pengelola secara langsung dalam perencanaan program, partisipasi dalam 
pelaksanaan program dan partisipasi dalam menikmati hasil dari program yang dijalankan.

\section{Tujuan Penelitian}

1. Mengidentifikasi program terkait tingkat partisipasi masyarakat dalam kegiatan program pengelolaan lingkungan permukiman berbasis komunitas (PLPBK).

2. Menganalisis pengembangan potensi modal sosial dan potensi ekonomi yang dimiliki masyarakat pinggiran sungai dengan adanya program pengelolaan lingkungan permukiman berbasis komunitas (PLPBK).

3. Menganalisis perubahan perilaku masyarakat (pengetahuan, keterampilan dan sikap masyarakat pinggiran sungai) terhadap penyelenggaraan program pengelolaan lingkungan permukiman berbasis komunitas (PLPBK).

\section{METODE PENELITIAN}

\section{Metode Penentuan Lokasi}

Penentuan lokasi penelitian dilakukan di wilayah kelurahan Pahandut Seberang, kecamatan Pahandut, kota Palangka Raya. Penentuan lokasi menggunakan metode porposive dengan alasan bahwa lokasi tersebut menjadi prioritas utama bagi kegiatan Program Pengelolaan Lingkungan Permukiman Berbasis Komunitas (PLPBK) di kota Palangka Raya. Kelurahan Pahandut Seberang terbagi atas 2 RW dan terdiri dari 9 RT, berdasarkan kriteria tersebut maka ditentukan dua RT yakni RT2 dan RT 3, di kelurahan Pahandut Seberang sebagai lokasi kegiatan pemberdayaan masyarakat, sekaligus sebagai lokasi penelitian.

\section{Metode Penentuan Sampel}

Sumber data berasal dari data primer yakni rumah tangga dan data sekunder yang diperoleh dari instansi terkait. Penentuan sampel dilakukan dengan random sampling, jumlah sampel yang diambil terpilih sebanyak 30 orang dari total populasi penduduk yang terlibat dalam kegiatan PLPBK. Metode pengumpulan data menggunakan "O bservasi M endalam" melakukan wawancara terbuka, Focus Group Discussion (FGD), dan evaluasi kegiatan program pembangunan fisik.

\section{Metode Analisis Data}

Metode analisis data dilakukan secara mixing berupa deskriptif kualitatif dan kuantitatif dengan menekankan pada data kondisi sosial ekonomi masyarakat, terkait dengan tingkat partisipasi masyarakatnya, dimana tahapan analisis data tersebut adalah:(1) Mengidentifikasi prasarana dan kelembagaan serta sarana yang terkait dengan partisipasi masyarakat dalam program PLPBK. (2) Mendeskripsikan kondisi prasarana dan kelembagaan serta sarana berdasarkan hasil identifikasi, dan (3) Menganalisis kondisi sosial ekonomi secara deskriptif-kualitatif dan kuantitatif berdasarkan hasil pembangunan fisik dan pelatihan serta penyuluhan pada masyarakat.

Analisis data untuk tingkat partisipasi masyarakat ditentukan dengan menggunakan skoring berdasarkan Skala Likert, yaitu meliputi cara: penentuan tingkat Partisipasi Rendah, Sedang, Tinggi, berdasarkan perhitungan pada penelitian ini membagikan kuisioner untuk 30 responden dengan jumlah pertanyaan yaitu 20 untuk menentukan tingkat partisipasinya. Pada kajian ini penentuan jumlah skala Likert adalah 5, dengan skala jawaban nilai Sangat Tidak Baik $=1$, Kurang Baik = 2, Cukup Baik = 3, Baik $=4$, Sangat Baik $=5$. Tingkat partisipasi komunitas dibagi dalam tiga kategori, yaitu Tinggi, Sedang, Rendah. 


\section{HASIL DAN PEMBAHASAN}

\section{Hasil Identifikasi Program Kegiatan Terkait Tingkat Partisipasi Masyarakat dalam Program Pengelolaan Lingkungan Permu- kiman Berbasis Komunitas (PLPBK)}

Kegiatan program pengelolaan lingkungan permukiman berbasis komunitas melalui pendanaan program PNPM-Mandiri Perkotaan dilaksanakan oleh Dinas Pekerjaan Umum Kota Palangka Raya, melalui 2 (dua) tahapan kegiatan yaitu pembangunan fisik dan pembangunan sumberdaya manusia. Pembangunan fisik berupa pembangunan jembatan penghubung antar RT, pembangunan WC atau kakus bagi warga, pembangunan tempat penampungan dan pembangunan saluran air bersih dengan menggunakan pipa-pipa ke rumah-rumah warga, serta pembuatan tempat sampah, sedangkan pembangunan SDM dan penguatan kelembagaan masyarakat dilakukanmelalui kegiatan sosialisasi, pelatihan dan penyuluhan kepada masyarakat sasaran.Kegiatan pelatihan yangdilakukan berupa pelatihan teknik budidaya ikan dalam karamba dan budidaya ikan dalam kolam, pelatihan penggolahan hasil ikan serta pelatihan lainnya di luar bidang perikanan seperti perbengkelan, menjahit, kerajinan tangan dan pembukuan, sedangkan untuk peningkatan kemampuan kesehatan dan kebersihan lingkungan dilakukan melalui kegiatan penyuluhan kebersihan dan kesehatan masyarakat (PHBS), serta penyuluhan hidup bersih dan sehat.

Hasil identifikasi kegiatan program dikaitkan dengan partisipasi masyarakat diuraikan sebagai berikut;

\section{Bidang Prasarana}

a. Partisipasi responden dalam kegiatan pembangunan jalan desa dan lingkungan untuk mempermudah komunikasi dengan pusat pelayanan pemerintah serta distribusi hasil-hasil pertanian telah berjalan dengan baik, kegiatannya melibatkan masyarakat mencapai $66,67 \%$, tergolong tinggi

b. Partisipasi dalam perbaikan jembatan kayu guna peningkatan kualitas jembatan sebagai sarana penghubung antar warga, telah melibatkan responden mencapai 50,00\%, tergolong tinggi.

c. Partisipasi dalam penataan jaringan listrik dan penerangan jalan umum melibatkan masyarakat, mencapai 43,33\%, tergolong sedang

d. Partisipasi dalam pembangunan fasilitas air bersih serta penataan saluran irigasi guna mengoptimalisasi pasokan sumber air bersih bagi warga dan antisipasi banjir melibatkan masyarakat, mencapai $53,33 \%$, tergolong tinggi

e. Partisipasi dalam pembangunan tempat pemasaran/pelelangan ikan (TPI), guna meningkatkan perekonomian masyarakat. Telah melibatkan responden mencapai $46,67 \%$, tergolong sedang.

2. Bidang Penyediaan Sarana

a. Partisipasi responden dalam akses transportasi untuk mempermudah komunikasi dengan pusat pelayanan pemerintah serta distribusi hasil-hasil pertanian telah berjalan dengan baik, kegiatannya melibatkan masyarakat mencapai $50,00 \%$, tergolong tinggi

b. Partisipasi dalam pelayanan koperasi, terutama terlibat sebagai anggota baru mencapai $60,00 \%$, tergolong rendah.

c. Partisipasi dalam pemanfaatan pelayanan kesehatan, mencapai 40,00\% tergolong sedang.

d. Partisipasi dalam pembangunan fasilitas taman di perumahan mencapai 53,33\%, tergolong tinggi.

3. Bidang Pemantapan Kelembagaan dan Pelatihan. 
1. Partisipasi responden dalam penentuan kelompok budidaya ikan dalam karamba, mencapai 56,67\%, tergolong tinggi

2. Partisipasi responden dalam pelatihan budidaya ikan dalam kolam, mencapai $53,33 \%$, tergolong sedang

3. Partisipasi responden dalam pelatihan pengelolaan hasil ikan, mencapai $53,33 \%$, tergolong tinggi

4. Partisipasi responden dalam pelatihan mengenai pembukuan dan pemasaran hasil mencapai 53,33\%, tergolong tinggi

Berdasarkan hasil analisis data menunjukkan bahwa identifikasi program terkait dengan tingkat partisipasi masyarakat, menunjukan angka yang cukup tinggi dan baik karena ratarata masyarakat terlibat secara partisipatif pada berbagai program yang telah direcanakan, yaitu program perbaikan dan pengembangan prasarana, kelembagaan dan sarana yag terkait dengan potensi sosial dan ekonomi masyarakat guna peningkatan tarap hidup dan kemandirian serta jati diri masyarakat.Hasil identifikasi kegiatan PLPBK yang dikaitkan dengan tingkat partisipasi masyarakat lebih lanjut disajikan pada Tabel 1.

Berdasarkan Tabel 1, dapat dilihat bahwa ratarata tingkat partisipasi masyarakat dalam PLPBK tergolong tinggi sebesar $46.41 \%$, terutama padaaktivitas pemantapan kelembagaan dan pelatihan, kemudian diikuti dengan partisipasi pada kegiatan pembangunan prasarana dan penyediaan sarana. Persentase dana yang terserap dalam kegiatan tersebut tergolong tinggi yakni mencapai 98,00\%, namun belum mencapai $100 \%$ karena keterbatasan masyarakat dalam kemampuan baik secara teknis dan keterampilan dalam hal pengelolaan penyelesaian tempat pelelangan ikan (TPI),terkait juga dengan kemampuan manajemen pengelolaan dan pembukuan yang

Tabel 1 Identifikasi Kegiatan program PLPBK dengan melibatkan partisipasi masyarakat di Kelurahan Pahandut Seberang Kota Palangka Raya, Tahun 2014-2015

\begin{tabular}{|c|c|c|c|c|c|c|c|}
\hline \multirow[b]{2}{*}{ No } & \multirow[b]{2}{*}{ Kegiatan } & \multirow[b]{2}{*}{ Implementasi } & \multirow{2}{*}{$\begin{array}{l}\text { Nilai } \\
\text { (Juta } \\
\text { Rp) }\end{array}$} & \multicolumn{3}{|c|}{ Tingkat Partisipasi (\%) } & \multirow{2}{*}{$\begin{array}{l}\text { \% dana } \\
\text { terserap }\end{array}$} \\
\hline & & & & Rendah & Sedang & Tinggi & \\
\hline \multirow[t]{5}{*}{1} & Pembangunan & 1. Jalan Desa & & 16,67 & 16,67 & 66,67 & \\
\hline & Prasarana & 2. Jembatan Kayu & & 20,00 & 26,67 & 53,33 & \\
\hline & & 3. Penerangan Listrik & & 13,33 & 50,00 & 33,33 & \\
\hline & & 4. Saluran Air Bersih & 500 & 23,33 & 33,33 & 43,33 & 96,00 \\
\hline & & $\begin{array}{l}\text { 5. Tempat Pelelangan } \\
\text { Ikan (TPI) }\end{array}$ & & 26,67 & 46,67 & 26,67 & \\
\hline \multirow[t]{4}{*}{2} & Penyediaan & 1. Akses Transportasi & & 20,00 & 30,00 & 50,00 & \\
\hline & Sarana & 2. Pelayanan Koperasi & & 60,00 & 26,67 & 13,33 & \\
\hline & & 3. Pelayanan Kesehatan & 250 & 23,33 & 40,00 & 36,67 & 98,00 \\
\hline & & 4. Taman di Perumahan & & 26,67 & 20,00 & 53,33 & \\
\hline \multirow[t]{6}{*}{3} & $\begin{array}{l}\text { Kelembagaan } \\
\text { dan }\end{array}$ & $\begin{array}{l}\text { 1. Pembentukan Kelom } \\
\text { pok budidaya ikan }\end{array}$ & & 16,67 & 26,67 & 56,67 & \\
\hline & Pelatihan & karamba & 250 & & & & \\
\hline & & $\begin{array}{l}\text { 2. Pembentukan Kelom } \\
\text { pok budidaya ikan } \\
\text { kolam }\end{array}$ & & 23,33 & 53,33 & 23,33 & 100,00 \\
\hline & & $\begin{array}{l}\text { 3. Pelatihan Pengolahan } \\
\text { Hasil Ikan }\end{array}$ & & 23,33 & 23,33 & 53,33 & \\
\hline & & $\begin{array}{l}\text { 4. Pelatihan Pembukuan } \\
\text { dan Pemasaran }\end{array}$ & & 16,67 & 30,00 & 53,33 & \\
\hline & Rata-rata 1 & ngkat Partisipasi & 1000 & 23,88 & 29,49 & 46,41 & 98,00 \\
\hline
\end{tabular}

Sumber data primer yang diolah, Tahun 2015 
masih kurang, karena kurangnya pengalaman serta merupakan hal baru bagi masyarakat menginggat kegiatan dibidang perikanan yang sebelumnya masih bersifat tangkap.

Sedangkan keterlibatan masyarakat dalam keanggotaan koperasi tergolong rendah tenyata mempengaruhi penyerapan dana, hal ini disebabkan oleh pengalaman terdahulu, di mana manajemen penggelolaan koperasi yang kurang baik dan tidak adanya keterbukaan antara pengelola dan anggotanya, menyebabkan keterlibatan masyarakat menjadi rendah, hal ini membutuhkan penyuluhan dan pembinaan yang lebih baik lagi.

\section{Pengembangan Potensi Modal Sosial dan Potensi Ekonomi Masyarakat}

Berdasarkan hasil analisis dan diskusi terfokus (FGD) dengan pelaksana program, tokoh masyarakat dan pihak terkait dalam merumuskan strategi PLPBK diperoleh tingkat partisipasi masyarakat dalam menumbuhkan dan menerapkan modal sosial untuk menyelesaikan kegiatan yang telah disepakati bersama dan unsur-unsur modal sosial yang dikembangkan dan terkait dengan penyelenggaraan PLPBK berupa"Sifat Sosial"hal ini meliputi kegiatan partisipatif (kemampuan responden dalam berpartisipasi pada kegiatan PLPBK dengan angka 64,07\% tergolong tinggi), resiprocity (kegiatan saling tukar informasi antar individu dalam PLPBK, dengan angka 36,26\% tergolong sedang), trust (rasa percaya-mempercayai, dan saling menghargai dalam PLPBK, dengan angka $61,37 \%$ tergolong tinggi), norma (sekumpulan aturan yang diberlakukan dalam PLPBK, dengan angka 58,92\% tergolong tinggi) dan nilai-nilai (sesuatu ide yang turuntemurun dan dianggap benar yang berlangsung pada PLPBK telah diikuti oleh seluruh responden, tergolong tinggi). Disimpulkan bahwa potensi modal sosial telah berjalan dengan baik dalam penerapan PLPBK. Hasil analisis potensi modal sosialdan potensi ekonomi yang diterapkan dan dicapai masyarakat, disajikan pada Tabel 2 dan Tabel 3.

Tabel 2 Hubungan Potensi Modal Sosial dengan Tingkat Partisipasi Masyarakat pada program PLPBK Tahun 2014-2015

\begin{tabular}{|c|c|c|c|c|c|c|}
\hline \multirow{2}{*}{ No } & \multirow{2}{*}{$\begin{array}{c}\text { Potensi } \\
\text { Modal Sosial }\end{array}$} & \multicolumn{2}{|c|}{ Responden (orang) } & \multicolumn{3}{|c|}{ Tingkat Partisipasi (\%) } \\
\hline & & n & Aktif & Rendah & Sedang & Tinggi \\
\hline \multirow[t]{5}{*}{1} & Partisipatif & 30 & & & & \\
\hline & a. Perencanaan & & 26 & 23,07 & 15,38 & 61,53 \\
\hline & b. Pelaksanaan & & 30 & 16,67 & 16,67 & 66,67 \\
\hline & c. Monev & & 25 & 16,00 & 20,00 & 64,00 \\
\hline & & & Rata-rata & 18,58 & 17,35 & 64,07 \\
\hline \multirow[t]{5}{*}{2} & Resiprocity & 30 & & & & \\
\hline & a. Mau bekerjasama & & 12 & 25,00 & 33,33 & 41,66 \\
\hline & b. Mau memberi informasi & & 22 & 18,18 & 45,45 & 36,36 \\
\hline & c. Mau bertanggungjawab & & 10 & 60,00 & 30,00 & 10,00 \\
\hline & & & Rata-rata & 34,39 & 36,26 & 29,34 \\
\hline \multirow[t]{5}{*}{3} & Trust & 30 & & & & \\
\hline & a. Rasa saling percaya & & 27 & 18,51 & 25,92 & 55,56 \\
\hline & b. Rasa saling membantu & & 28 & 14,28 & 21,42 & 64,28 \\
\hline & c. Rasa saling mengingatkan & & 28 & 14,28 & 21,42 & 64,28 \\
\hline & & & Rata-rata & 15,69 & 22,92 & 61,37 \\
\hline \multirow[t]{5}{*}{4} & Norma & 30 & & & & \\
\hline & a. Taat Aturan non-formal & & 30 & 3,33 & 3,33 & 93,33 \\
\hline & b. Taat Hukum adat & & 30 & 0 & 0 & 100 \\
\hline & c. Taat Hukum formal, & & 30 & 0 & 0 & 100 \\
\hline & & & Rata-rata & 1,11 & 1,11 & 97,77 \\
\hline \multirow[t]{6}{*}{5} & Nilai-nilai & 30 & & & & \\
\hline & a. Kesederhanaan & & 26 & 7,69 & 11,53 & 80,76 \\
\hline & b. Pengabdian & & 25 & 20,00 & 28,00 & 52,00 \\
\hline & c. Nilai Nasional & & 25 & 28,00 & 28,00 & 44,00 \\
\hline & & & Rata-rata & 18,56 & 22,51 & 58,92 \\
\hline & Rata-rata Tingkat & & & 17,66 & 20,03 & 62,29 \\
\hline
\end{tabular}


Sedangkan potensi ekonomi, yang telah dimanfaatkan masyarakat dengan adanya PLPBK yang ada berupa pengembangan usaha perikanan berbasis kondisi lokal, meliputi budidaya ikan dalam karamba $(62,95 \%$ responden telah melakukan) dan budidayaikan dalam kolam $(37,78 \%$ responden telah melakukan) dan pengolahan hasil ikan menjadi bentuk lain seperti pembuatan abon dan kerupuk ikan $(57,80 \%$ responden melakukan). Dengan tingkat partisipasi rata-rata sebesar $46,06 \%$. Sebagian besar $(75 \%)$ responden telah berpartisipasi dalam mengikuti pelatihan lebih dari 2 kali usaha-usaha ini sudah dikembangkan melalui kegiatan pelatihan budidaya serta pendampingan dalam kegiatan praktik budidaya dan praktik pengolahan hasil ikan dalam bentuk abon dan kerupuk ikan di lahan masyarakat.

Pemilihan kegiatan PLPBK yang direalisasikan melalui anggaran Bantuan Langsung Masyarakat (BLM), sekaligus mempersiapkan programprogram non Bantuan Langsung Masyarakat (non BLM) untuk dipasarkan kepada stakeholder yang tepat. Keterlibatan forum BKM kelurahan Pahandut Seberang dalam memasarkan program pembangunan antar wilayah kelurahan secara terpadu dan terintegrasi difokuskan kepada pemerintah kota Palangka Raya.

Tabel 3 Hubungan Potensi Modal Ekonomi dengan Tingkat Partisipasi Masyarakat pada program PLPBK Tahun 2014-2015

\begin{tabular}{|c|c|c|c|c|c|c|}
\hline \multirow{2}{*}{ No } & \multirow{2}{*}{$\begin{array}{c}\text { Potensi } \\
\text { Ekonomi }\end{array}$} & \multicolumn{2}{|c|}{ Responden (orang) } & \multicolumn{3}{|c|}{ Tingkat Partisipasi (\%) } \\
\hline & & $\mathbf{n}$ & Aktif & Rendah & Sedang & Tinggi \\
\hline \multirow[t]{5}{*}{1} & Perikanan Tangkap & 30 & & & & \\
\hline & a. Dilakukan sendiri & & 12 & 25,00 & 25,00 & 50,00 \\
\hline & b. Melibatkan anggota keluarga & & 22 & 27,27 & 36,36 & 36,36 \\
\hline & c. Melibatkan tetangga/teman & & 10 & 60,00 & 30,00 & 10,00 \\
\hline & & & Rata-rata & 37,42 & 30,45 & 32,12 \\
\hline \multirow[t]{5}{*}{2} & Budidaya Karamba & 30 & & & & \\
\hline & a. Dilakukan sendiri & & 26 & 11,53 & 26,92 & 61,53 \\
\hline & b. Melibatkan anggota keluarga & & 30 & 16,67 & 20,00 & 63,33 \\
\hline & c. Melibatkan tetangga/teman & & 25 & 20,00 & 16,00 & 64,00 \\
\hline & & & Rata-rata & 16,06 & 20,97 & 62,95 \\
\hline \multirow[t]{5}{*}{3} & Budidaya Kolam & 30 & & & & \\
\hline & a. Mengikuti sendiri & & 30 & 23,33 & 33,33 & 43,34 \\
\hline & b. Mengajak anggota keluarga & & 30 & 30,00 & 40,00 & 30,00 \\
\hline & c. Mengajak tetangga/teman & & 30 & 26,67 & 33,33 & 40,00 \\
\hline & & & Rata-rata & 26,67 & 35,55 & 37,78 \\
\hline \multirow[t]{5}{*}{4} & Pembuatan Abon dan Kerupuk Ikan & 30 & & & & \\
\hline & a. Mengikuti sendiri & & 27 & 14,81 & 29,62 & 55,56 \\
\hline & b. Mengajak anggota keluarga & & 28 & 25,00 & 25,00 & 50,00 \\
\hline & c. Mengajak tetangga/teman & & 28 & 21,42 & 10,71 & 67,85 \\
\hline & & & Rata-rata & 20,41 & 21,77 & 57,80 \\
\hline \multirow[t]{6}{*}{5} & Pembentukan Kelembagaan & 30 & & & & \\
\hline & a. Mengikuti sendiri & & 26 & 26,92 & 34,61 & 30,76 \\
\hline & b. Mengajak anggota keluarga & & 25 & 20,00 & 28,00 & 52,00 \\
\hline & c. Mengajak tetangga/teman & & 25 & 16,00 & 16,00 & 68,00 \\
\hline & & & Rata-rata & 20,97 & 26,20 & 50,25 \\
\hline & Rata-rata Tingkat Partisipasi & & & 21,75 & 26,04 & 46,06 \\
\hline
\end{tabular}

Sumber data primer yang diolah, Tahun 2015 
Hasil analisis menunjukkan bahwa pada kegiatan yang memanfaatkan potensi ekonomi menunjukan bahwa partisipasi masyarakat menunjukkan nilai tinggi dengan rata-rata $46,06 \%$, capaian ini menggambarkan bahwa keinginan masyarakat untuk meningkatkan tarap hidupnya tergolong tinggi, karena pada umumnya masyarakat adalah petani tangkap $(37,42 \%)$, dengan hasil yang tidak maksimal karena hasil tangkapan masih dipengaruhi oleh faktor alam, sedangkan untuk pengelolaan budidaya ikan dalam kolam masih belum maksimal karena untuk kolam membutuhkan lahan kering yang cukup baik untuk pembuatan kolamnya, sedangkan di kelurahan Pahandut Seberang pengelolaan kolamnya masih belum maksimal karena merupakan permukiman pinggir sungai.

\section{Hasil Perubahan Perilaku Masyarakat (pengetahuan, keterampilan dan sikap) dalam kegiatan PLPBK}

Perubahan perilaku masyarakat setelah adanya kegiatan PLPBK menunjukan tingkat perubahan pengetahuan dan perubahan keterampilan mencapai 30\%, perubahan sikap untuk berpartisipasi mengelola lingkungan mencapai $40 \%$ dilihat dari indikator pengambilan keputusan, kemampuan komunikasi, motivasi, sifat dan kondisi konflik di dalam masyarakat. Hal ini menunjukkan bahwa masyarakat secara baik menerima program PLPBK ini, namun masih belum mampu meningkatkan perilaku masyarakat kearah yang lebih baik dalam usaha berkembang perekonomian dan pola kehidupan yang lebih baik dan sehat sesuai dengan tujuan program PLPBK. Hasil penelitian ini menggambarkanmodel partisipasi masyarakat dalam PLPBK yang bertujuan untuk meningkatkan kemandirian masyarakat secara sosial maupun secara ekonomi dengan melihat potensi diri dan lingkungan tempat tinggal masyarakat yang ada dan dapat dikembangkan secara maksimal guna peningkatan tarap hidup masyarakat yang berjati diri.

Hasil analisis menggambarkan model perubahan perilaku responden, seperti disajikan pada Gambar 2.

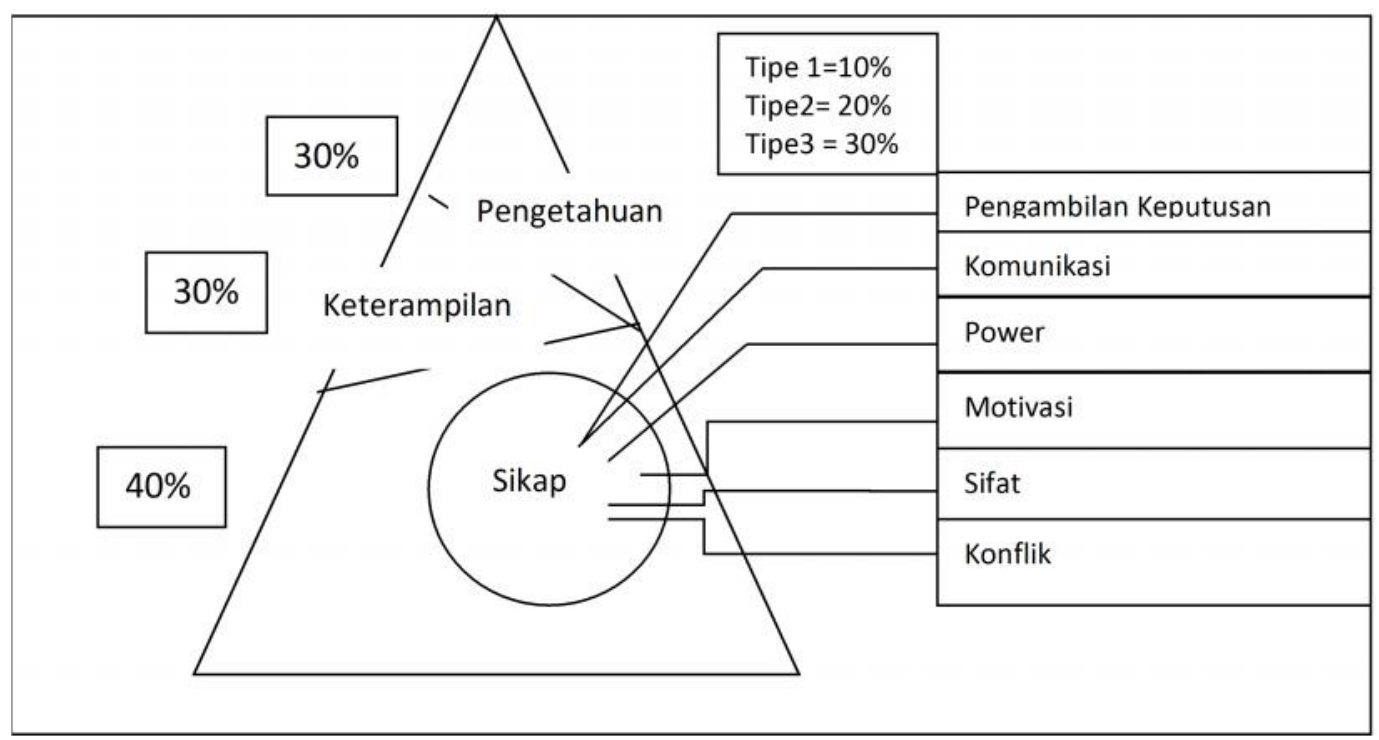

Gambar 2 Tingkat Perubahan Perilaku Masyarakat Pinggir Sungai 


\section{KESIMPULAN DAN SARAN}

\section{Kesimpulan}

Tingkat partisipasi masyarakat menunjukan tingkat keterlibatan masyarakat dalam berbagai kegiatan, dalam hal ini menunjukan keterlibatan masyarakat dalam program PLPBK. Hasil penelitian ini menunjukan bahwa:

1. Berdasarkan hasil analisis data menunjukan bahwa identifikasi program terkait dengan tingkat partisipasi masyarakat, menunjukan angka partisipasi yang cukup tinggi dan baik karena rata-rata $46,41 \%$, masyarakat terlibat secara partisipatif pada berbagai program yang telah direncanakan, sedangkan dana yang terserap mencapai $98 \%$ meliputi kegiatan program perbaikan dan pengembangan serta pembangunan prasarana, penyediaan sarana serta kelembagaan dan pelatihan yang terkait dengan potensi sosial dan ekonomi masyarakat.

2. Hasil analisis pengembangan modal sosial meliputi partisipasi, resiprocity, trust, norma dan nilai-nilai dalam masyarakat menunjukan bahwa perkembangannya kearah lebih baik terlihat dari penerimaan dan keterlibatan masyarakat terhadap program yang dilaksanakan pada tingkat yang tinggi sebesar 62,29\%, namun perlu ditingkatkan menjadi modal yang kuat untuk membentuk jati diri masyarakat yang kuat.

3. Berdasarkan hasil analisis, dari 30 responden bahwa perubahan perilaku secara umum, setelah adanyakegiatan PLPBK menunjukkan tingkat pengetahuan dan keterampilan masyarakat meningkat sebanyak 30\%, sikap atau keinginan masyarakat untuk mengelola lingkungan dengan baik, berbasis sosial dan ekonomi masyarakat mengalami peningkatan sebanyak $40 \%$ dilihat dari indikator pengambilan keputusan, kemampuan komunikasi, motivasi, sifat dan kondisi konflik di dalam masyarakat. Hal ini menun- jukkan bahwa masyarakat secara baik menerima program PLPBK ini, serta mampu meningkatkan perilaku masyarakat kearah yang lebih baik dalam usaha berkembang perekonomian dan pola kehidupan yang lebih baik dan sehat sesuai dengan tujuan program PLPBK.

\section{Saran}

Hasil kegiatan PLPBK ini memberikan dampak yang positif bagi masyarakat pinggiran sungai di Kota Palangka Raya, namun kegiatan ini masih perlu perhatian dan peningkatan pelayanan dari pemerintah agar pengembangan jiwa enterpreneurship masyarakat melalui pelatihan yang berdasar pada kebutuhan masyarakat masih perlu dilakukan, sehingga bisa berkelanjutan untuk membentuk masyarakat yang mandiri dan berjati diri.

\section{DAFTAR PUSTAKA}

Asnar. 2016. Partisipasi Masyarakat Dalam Pembangunan di Kelurahan Sidomulyo Kecamatan Samarinda Ilir Samarinda. Gulawentah. Jurnal Studi Sosial Vol. 1 No.2 Desember 2016, Hal. 121-131 Avaliable Online:Http://E-Journal. Ikippgrimadiun.Ac.Id/Index.Php/ Gulawentah. Universitas Mulawarman Samarinda.

Badan Pusat Statistik. 2014. Kota Palangka Raya Dalam Angka Tahun 2014. Palangka Raya, Kalimantan Tengah.

Fadil, Fathurrahman. 2013. Partisipasi Masyarakat Dalam Musyawarah Perencanaan Pembangunan di Kelurahan Kotabaru Tengah. Jurnal Ilmu Politik dan Pemerintahan Lokal, Volume II Edisi 2, JuliDesember 2013. Fakultas Ilmu Sosial dan Ilmu Politik Universitas Lambung Mangkurat. 
Genius. 2013. Partisipasi Masyarakat Dalam Program Nasional Pemberdayaan Masyarakat Mandiri Pedesaan (PnpmMp) Di Kelurahan Tembeling Tanjung Kecamatan Teluk Bintan Kabupaten Bintan Tahun 2011. Naskah Publikasi Hasil Penelitian. Program Studi Ilmu Pemerintahan Fakultas Ilmu Sosial dan Politik Universitas Maritim RajaAli Haji Tanjungpinang.

Hikmat.2012. Strategi Pemberdayaan Masyarakat. Penerbit Humoniora. Bandung.

Kogoya, Teraik, Benu Olfie, dan Olly Esry Laoh. 2015. Partisipasi Masyarakat Terhadap Pembangunan Infrastruktur Jalan Desa di Kabupaten Lanny JayaPapua. Jurnal Berkala Ilmiah Efisiensi Volume 15 No. 2-Juni 2015. Program Studi Perencanaan Pengembangan Wilayah, Universitas Sam Ratulangi, Manado.

Mardikanto, Totok. 2010. Komunikasi Pembangunan. Acuan Bagi Akademisi, Praktisi dan Peminat Komunikasi Pembangunan. Program Studi Pemberdayaan Masyarakat. Program Pascasarjana, Universitas Sebelas Maret, Surakarta.

Mardjoeki, H. 2012. Pemberdayaan Masyarakat Pesisir Pantai Utara Daerah Kabupaten Cirebon. Jurnal Ekonomi ISSN: 2302-7169, Vol. 1. No. 1. September-Desember 2012.

Monografi Kelurahan Pahandut Seberang. Tahun 2014. Kelurahan Pahandut Seberang Kota Palangka Raya, Kalimantan Tengah.
Olfie L. S, Bryan Repi Benu. Oktavianu Porajow Jean. F. J. Timban. 2015. Partisipasi Masyarakat Terhadap Pembangunan Infrastruktur Jalan Melalui PNPM-PPIP Di Desa Munte Kecamatan Tumpaan Kabupaten Minahasa Selatan. Jurnal Ase-Vol. 11 No.1, Januari 2015: 38-50.

Parma, I Putu Gede. 2011. Faktor-Faktor Pendorong Partisipasi Masyarakat Dalam Festival Pesona Pulau Serangan di Kota Denpasar. Jurnal Perhotelan dan Pariwisata, Desember 2011, Vol.1 No.2 hal.1. Sekolah Tinggi Pariwisata Triatma Jaya, Gede Ginaya. Bali.

PNPM-Mandiri Perkotaan. 2015. Wilayah Kerja Kota Palangka Raya Tahun 2014-2015. Dinas Pekerjaan Umum Kota Palangka Raya, Kalimantan Tengah.

Purwatiningsih, A Ismani 2014. Faktor-faktor yang Mempengaruhi Partisipasi Politik Masyarakat dalam Pembangunan Desa. Jurnal ilmiah Administrasi Publik FIA, Vol.IV, No.2, 1-24.

Yuliati, Yoni. 2012. Analisis Partisipasi Masyarakat dalam Pelaksanaan Program Nasional Pemberdayaan Masyarakat (PNPM) Mandiri Perkotaan di Kota Solok. Program Pascasarjana Universitas Andalas Padang. 